\title{
Linking Forests and Food Production in the REDD+ Context
}

Working Paper No. 1

CGIAR Research Program on Climate Change, Agriculture and Food Security (CCAFS)

Gabrielle Kissinger

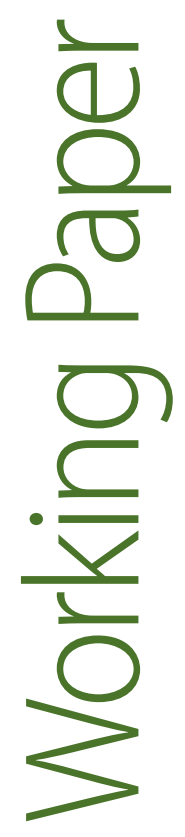




\section{Linking Forests and Food Production in the REDD+ Context \\ Working Paper No. 1}

CGIAR Research Program on Climate Change, Agriculture and Food Security (CCAFS)

Gabrielle Kissinger 


\section{Correct citation:}

Kissinger G. 2011. Linking forests and food production in the REDD+ context. CCAFS Working Paper no. 1. CGIAR Research Program on Climate Change, Agriculture and Food Security (CCAFS).

Copenhagen, Denmark. Available online at: www.ccafs.cgiar.org

Titles in this Working Paper series aim to disseminate interim climate change, agriculture and food security research and practices and stimulate feedback from the scientific community.

Published by the CGIAR Research Program on Climate Change, Agriculture and Food Security (CCAFS).

CCAFS Coordinating Unit - Department of Agriculture and Ecology, Faculty of Life Sciences, University of Copenhagen, Rolighedsvej 21, DK-1958 Frederiksberg C, Denmark. Tel: +45 35331046; Email: ccafs@life.ku.dk

Creative Commons License

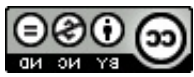

This Working Paper is licensed under a Creative Commons Attribution - NonCommercial-NoDerivs 3.0 Unported License.

Articles appearing in this publication may be freely quoted and reproduced provided the source is acknowledged. No use of this publication may be made for resale or other commercial purposes.

(C) 2011 CGIAR Research Program on Climate Change, Agriculture and Food Security (CCAFS) 2011 CCAFS Working Paper no. 1

DISCLAIMER:

This Working Paper has been prepared as an output for the Pro-Poor Mitigation Theme under the CCAFS program and has not been peer reviewed. Any opinions stated herein are those of the author(s) and do not necessarily reflect the policies or opinions of CCAFS. 


\begin{abstract}
In order for REDD+ carbon emission mitigation targets to be reached, the primary driver of forest clearing globally, agriculture, must be fundamentally addressed by governments implementing REDD+ Programmes. This paper evaluates the extent to which countries participating in the World Bank Forest Carbon Partnership Facility (FCPF) readiness activities are actively linking REDD+ and agriculture policies, programmes, and institutional and governance arrangements. Based on 20 current country readiness proposals (R-PPs) submitted to the FCPF, the analysis reveals that overall, REDD+ strategies and actions generally fail to address agricultural drivers. The paper poses a general roadmap for how countries can more adequately address agricultural drivers in their REDD + strategies, including: identifying clear strategies to address demand-side and market pressures, and how government action can influence those; sorting out tenure and land access rights; strengthening cross-sectoral policies; linking mitigation to adaption; boosting efficiency and production of agricultural systems; and incorporating agricultural carbon measurement in national MRV systems. Brazil and Acre State, Brazil, are highlighted as a case study, as both jurisdictions have overcome, at the national and sub-regional scale, many of the hurdles faced by other governments analysed in this paper.
\end{abstract}

\title{
Keywords
}

REDD+; agriculture; drivers; deforestation; governance; forest policy 


\section{About the authors}

Gabrielle Kissinger: Lexeme Consulting, 3552 West $8^{\text {th }}$ Avenue, Vancouver, B.C. Canada. Phone: +1 604346 6474, E-mail: gabrielle@lexemeconsulting.com

Gabrielle Kissinger is principal of Lexeme Consulting in Vancouver, Canada. Consulting services focus primarily on international forest carbon, REDD+, government affairs and corporate social responsibility. She has almost 20 years of experience working at the interface between government policy and land use pressures. She has produced results working in partnership with various levels of government, companies ranging from start-ups to large timber companies, investors, major donors and a full range of environmental NGOs. Her research applies an interdisciplinary approach to find tenable solutions by drawing from ecological economics, ecology and conservation science, and public policy. Her work has served multiple geographic regions, from the Great Bear Rainforest in coastal British Columbia, Canada, to northern New England in the US and Lesotho, Southern Africa. She holds a M.A. in natural resources management and environmental policy from Tufts University and B.A.'s in philosophy and political science from University of California, Santa Barbara. 


\section{Acknowledgements}

This research was a partnership between Lexeme Consulting and the CGIAR Research

Program, Climate Change, Agriculture and Food Security (CCAFS). The author gratefully acknowledges Lini Wollenberg, Henry Neufeldt, Hosny El Lakany, Anthony Anderson, Alison Nihart, Vanessa Meadu, and Romain Pirard. The author is responsible for any errors. 


\section{Contents}

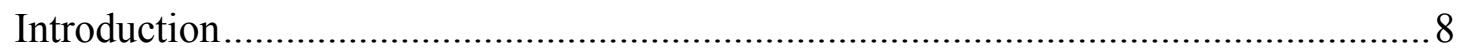

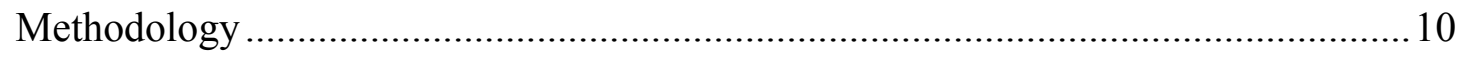

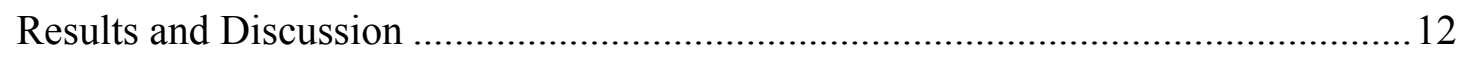

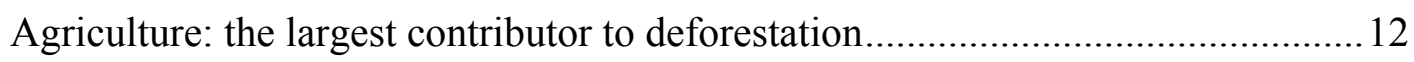

Adequacy of the policy and programmatic response .............................................. 14

Overcoming institutional and economic hurdles .................................................. 16

Case study: Success in Brazil and the State of Acre..................................................2

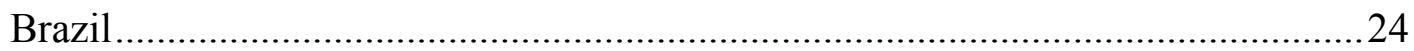

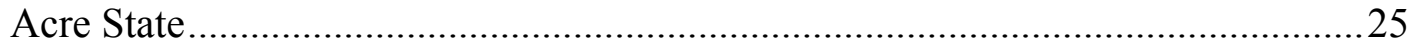

Roadmap for how to address agricultural drivers in REDD+ strategies......................2 28

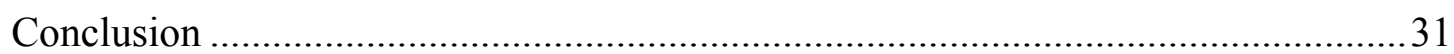

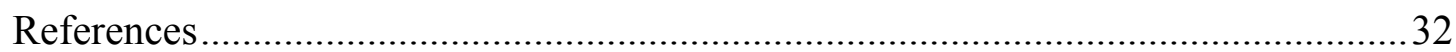




\section{Acronyms}

D\&D

DRC

FAO

FCPF

GHG

Lao PDR

LULUCF

NAFTA

MOA

MOE

MRV

NTFP

PES

PFM

R-PP

R-Plan

SFM

REDD+

UN-REDD
Deforestation and degradation

Democratic Republic of the Congo

United Nations Food and Agriculture Organization

World Bank Forest Carbon Partnership Facility

Greenhouse gas(es)

Lao People's Democratic Republic

Land Use, Land-Use Change and Forestry

North America Free Trade Agreement

Ministry of Agriculture

Ministry of Environment

Measuring, reporting, verification

Non-timber forest product

Payments for ecosystem services

Participatory Forest Management

World Bank FCPF REDD+ Readiness Proposal

World Bank FCPF REDD+ Plan

Sustainable Forest Management

Reductions in emissions from deforestation and forest degradation, and

promote conservation, sustainable management of forests and enhancement

of forest carbon stocks in developing countries

United Nations Framework Convention on Climate Change

United Nations REDD-Programme 


\section{Introduction}

REDD + is a set of policy approaches and positive incentives to reduce emissions from deforestation and forest degradation, and promote conservation, sustainable management of forests and enhancement of forest carbon stocks in developing countries. Adopted in Cancún, Mexico at the 16th meeting of the United Nations Framework Convention on Climate Change (UNFCCC) Conference of Parties, the REDD+ agreement enables the first global mechanism under the UNFCCC to address the large contribution of forest carbon emissions - currently 12$15 \%$ annually (van der Werf 2009) — to global greenhouse gas (GHG) emissions.

Recent remote sensing, combined with population and economic trends, illustrates that agricultural production for domestic urban growth and agricultural exports to other countries are the primary drivers of tropical deforestation, with the impact of smallholders decreasing (DeFries et al. 2010). The Food and Agriculture Organization predicts that the world's population will increase $34 \%$, to approximately 9.1 billion people, by 2050 . Additionally, consumption patterns will change, resulting in a $70 \%$ increase in the demand for food by 2050 , with a $49 \%$ increase in the volume of cereals produced and an $85 \%$ increase in the volume of meat produced (FAO 2009). While yield increases can satisfy some of this demand, the expansion of agriculture into forest areas is inevitable. Rainforests were the primary source for new agricultural land throughout the 1980s and 1990s, with over $80 \%$ of new agricultural land coming from intact and disturbed forests, rather than previously cleared land, and this trend is expected to continue (Gibbs et al. 2010). Simply closing off areas to agricultural production will not deliver long-term food supply needs.

Agricultural productivity is expected to decrease in non-temperate regions of the world, while productivity will increase in the temperate zones of North America, Europe and Asia. The anticipated result for developing, non-temperate countries is that they will need to import more food-a projected $45-50 \%$ increase in total net cereal import volume by 2050 relative to the year 2000. Additionally some predict price increases of $20 \%$ in the short to medium term (Hoffman 2011). Agriculture has become the most important and controversial issue in the Doha Round, with pressure from the European Union and the developing countries, led by Brazil and India, applied to the US to reduce its domestic support for agriculture, thus increasing developing country export opportunities (European Parliament 2010). While a settlement of the Doha Round may boost developing country exports to the temperate north in the short term, the resulting increase in demand for agricultural products will challenge tropical countries facing increasing climate change impacts to agricultural systems. Thus, tropical countries face considerable challenges ahead, and will need to balance climate change impacts to agricultural systems with both the growing demand for food, and rising food prices.

Within the UNFCCC, there is debate as to how to include the agricultural sector in the emissions reduction strategies that are currently being negotiated. Land use emissions account for $30 \%$ of 
global GHG emissions (IPCC 2007). This paper focuses on how REDD + readiness strategies must respond to and incorporate agricultural drivers of forest clearing, and argues that countries must not wait for the UNFCCC to agree whether and how to include agriculture in international climate change agreements. Countries pursuing the REDD + pathway will increase their success in meeting their REDD+ mitigation targets and goals by directly addressing agricultural drivers of forest clearing and developing the policy, governance, MRV mechanisms, and benefit-sharing necessary to impact agriculture's role in unsustainable forest conversion and emissions.

This paper evaluates the extent to which countries participating in the World Bank Forest Carbon Partnership Facility (FCPF) readiness activities are actively linking REDD + and agriculture policies, programmes, and institutional arrangements based on 20 current country readiness proposals (R-PPs) submitted to the FCPF. Brazil and Acre State, Brazil are highlighted as a case study, as considerable hurdles identified in the country investigation of FCPF R-PP's have been overcome:

- While a recent drop in soybean commodity prices may have affected agricultural expansion in the Amazon, there is clear evidence of a national deforestation target and national agricultural policy being linked. Recent deforestation rates have decreased, while agricultural production increased (see section 3.5). It should be noted that this activity commenced in advance of more formalized REDD + arrangements, which are still under development.

- The goal is to link all scales (national, state, local) in Brazil's emergent REDD+ strategy, with state targets and strategies being nested in national economy-wide targets.

- Acre State's REDD+ programme encompasses all lands and use types, including the fullrange of agricultural uses that impact Acre's forests; it offers a mix of incentives and payments, bundled under an umbrella REDD+ programme tied directly into the Acre Sustainable Development Plan; its emissions reduction targets are nested within federal targets; it is based on multi-sectoral land use plans; and governance of the programme appears strong, with enforcement ability. 


\section{Methodology}

The most current country REDD+ Readiness Proposals (R-PP) submitted to the World Bank Forest Carbon Partnership Facility, available on the FCPF website, were reviewed. Countries participating in the FCPF were chosen rather than countries participating in UN-REDD Programme, as there are more of them receiving assistance (24 as compared to 13), and five countries currently participate in both-DRC, Indonesia, Panama, Tanzania, and Viet Nam. Although 37 countries are participating in the FCPF, only those at the REDD+ Programme readiness proposal or readiness plan stage were reviewed. Furthermore, only those with enough documentation in English were reviewed (thus Central African Republic (R-PP in French), Nicaragua and Peru (R-PP's in Spanish) were omitted). Indonesia's UN-REDD National Joint Programme Document submission (dated October 2009) contained more detail than its May 2009 FCPF submission, so the UN-REDD submission was relied upon. The following countries were included in the REDD+ readiness plan review:

Africa: DR of Congo, Ethiopia, Ghana, Kenya, Liberia, Madagascar, Republic of Congo, Tanzania, Uganda

Asia: Cambodia, Indonesia, Lao PDR, Nepal, and Vietnam

Latin America: Argentina, Costa Rica, Guyana, Mexico, Panama, and Suriname

Country submissions were evaluated against the following criteria:

1) Are the scope and scale of current and future agricultural sector or related land use D\&D drivers accounted for in the R-PP?

2) Are the proposed REDD + policy and programmatic interventions adequate to affect the scope and scale of agricultural drivers?

3) Are the government ministries or agencies that can directly affect agricultural or related drivers either planning to or actively engaged in altering their plans and/or mandates to accommodate REDD+ strategies and objectives? Does the government (via the lead REDD+ agency, multi-sector committees, etc.) have the means to reconcile conflicting policies with the REDD+ country objectives?

Analysis of the R-PP's was based entirely on the content of the country submissions. The FCPF R-PP template encourages countries to assess direct and indirect drivers of D\&D and factors both within and outside the forest sector, major land use trends and forest policy and governance issues. Further, the FCPF requests countries to assemble multi-sectoral approaches to the countries' REDD+ readiness government response. 
The purpose of the FCPF Readiness Phase is to support countries transitioning into REDD+ program and institutional development, and implementation. Thus, R-PP documents identify potential REDD+ strategies, based on stakeholder engagement and inter-ministerial consultations, which will lead countries toward adoption of a final REDD+ plan. The FCPF template requests country submissions to identify structure of REDD-decision-making and institutions established or planned, existing policy and governance affecting REDD+, feedback and input from stakeholder consultations, and candidate REDD+ strategy options, based on that input (among other information requests). As such, this assessment is meant to be preliminary and coarse in nature, based on information available, not final country REDD + strategies and plans.

While not participating in the FCPF process, Brazil is participating in the Forest Investment Programme as a pilot country, and has signed a bilateral partnership agreement with the Government of Norway. What makes Brazil stand out as a case study is not only its extensive, carbon-rich tropical forests, but its remarkable track-record of overcoming many obstacles identified in the country investigation of FCPF R-PP's, such as multi-sectoral engagement and agreement and decreased national deforestation rates, with increased agricultural production. Recent updates to the California Governor's Climate and Forests Task Force on Brazil and Acre were reviewed, along with federal and state legislation. 


\section{Results and Discussion}

\section{Agriculture: the largest contributor to deforestation}

The first criterion R-PPs were evaluated against was: Are the scope and scale of current and future agricultural sector or related land use D\&D drivers accounted for in the R-PP? A country with a checkmark in the second column of Table 1 indicates agricultural production and expansion is reported as the primary driver of deforestation and degradation. Of 20 countries reviewed, 16 report agriculture as the primary driver of D\&D. Agricultural drivers of D\&D include a full range of clearing activities related to plant and animal-based food products, ranging from smallholder impacts to large-scale commercial and industrial agriculture production, primarily soybean, oil palm and cattle for meat production. Ethiopia reports population expansion into forest areas and the related resource needs, such as agriculture and livestock management combined with use of fire as the primary driver. Many countries cite shifting cultivation as the primary driver; however the extent of the impact in Liberia is particularly acute, with 5.1 million hectares, or half of the country's land area, affected.

Of the 4 countries that did not cite agricultural production as the primary driver, either forestry or mining are cited as primary drivers, while agricultural impacts are still measurable. For instance, Suriname cites mining as the primary driver (though offers no specific estimates) followed by population growth, agricultural plantations and biofuel production as other key drivers, and the numbers support agriculture's importance: 100,000 hectares were recently cleared in the northern interior region for oil palm plantations and the 2004 Agricultural Sector Plan seeks to promote cultivation in the 1.5 million hectares along the coastal area, which will compromise valuable mangrove forests.

Insufficient information was provided in some country submissions to attribute 'primary D\&D driver' status to any one particular land use. Agricultural drivers vary between regions, especially in large and geographically diverse countries. Indonesia reports that smallholder agriculture is the key driver in Sulawesi, whereas in Kalimantan and Sumatra, it is primarily due to the mechanized logging of lowland forest with a second stage of clearance for oil palm and pulpwood plantations. Indonesia unfortunately does not provide enough detail in its FCPF and UN-REDD submissions to ascertain the amount of deforestation attributed to each D\&D driver, thus Table 1 reflects this uncertainty. However, Indonesia's overall deforestation rate between 2003 and 2006 was about 1.17 million hectares per year. It is well documented that conversion for oil palm plantations occurs at a large scale (Koh 2011), and has a dramatic impact on carbon emissions due to the immense carbon storage in the forest and peat soils throughout Indonesia.

Adding to the complexity of the role of agriculture as a driver of D\&D in countries participating in REDD + is the myriad of underlying drivers that enable land conversion and unsustainable use of resources. Costa Rica, DR Congo, Ethiopia, Ghana, Kenya, Lao PDR, Liberia, Nepal, Madagascar and Tanzania directly cite governance and institutional failures, including 
inadequate enforcement, as critical underlying drivers that REDD+ strategies must address. The low financial returns of forest use in comparison with alternate uses, the 'tragedy of the commons' where lack of local user rights, inadequate land tenure and common access acts as a disincentive for sustainable forest resource use.

The third column in Table 1 indicates whether agricultural drivers of D\&D are primarily commercial and/or industrial or predominantly caused by smallholders. Argentina and Vietnam offer the boldest examples. Industrial soybean cultivation accounts for $70 \%$ of Argentine deforestation. Vietnam's export commodities - coffee, cashew, pepper, shrimp (affecting coastal mangroves), rice and rubber - drive forest conversion, and future agricultural policies will increase production for rubber and cashew, while stabilizing coffee production. Ghana reports varietal changes in cocoa (from shade-grown to full-sun varieties) as having a dramatic effect on deforestation in the high forest zones. Other countries with significant commercial/industrial impacts on forests are: Lao PDR (plantations fuelled by foreign direct investment), Costa Rica (meat exports to the US, promoted by government lending policies), Mexico ( $82 \%$ of deforestation due to agriculture or grazing, with NAFTA significantly influencing amount of exports into the US), and Tanzania (increasing biofuel production). Most countries (15 out of 20) indicate increasing commercial/industrial agricultural land use, particularly serving export and urban markets, and biofuel production.

Based on the information provided in the R-PP's, it is very difficult to identify the impacts of food-production versus non-food related agriculture (largely rubber, palm oil for non-food uses; and corn, sugarcane vegetable oils and animal fats for biofuels; and sugar cane, corn, sorghum for bioethanol) on forestland clearing, in terms of hectares cleared per year and projections into the future. Countries experiencing commercial/industrial scale agriculture-related forest clearing largely cite food production as the primary driver (meat exports, rice, coffee, sugarcane). While Indonesia's R-PP includes very little information about this well-documented driver of Indonesian forest-and peat-land clearing, Liberia's current palm oil investment proposals amount to $\$ 2.95$ billion, covering 494,500 hectares. Argentina and Cambodia cite biofuels as a future factor, but do not offer specific figures on existing and projected areas to be used in plantations. Vietnam and Cambodia cite rubber production as a primary cause of land conversion.

The impacts of smallholder agricultural clearing are largely tied to poverty, lack of tenure and access rights (or communal rights, with inadequate incentives for stewardship), and poor agricultural practices resulting in soil degradation (particularly cited by Uganda and Madagascar). In Cambodia, $60 \%$ of the population is dependent on agriculture, with $41 \%$ rural households deriving between 20 to $50 \%$ of their total livelihood value from forest use. Poverty is a particular driver of smallholder incursions into forests in DR Congo, Ghana, Kenya, Nepal, and Madagascar. The lack of tenure or need to clarify tenure rights affects smallholders in Ethiopia, Ghana, Nepal, Madagascar, Mexico, Suriname, Uganda, Tanzania and Vietnam. In the Democratic Republic of the Congo, the communal property/customary use tradition, with no license/permitting requirements for smallholders, results in an absence of formal institutions and processes to guide land use decisions. 
Table 1: Agriculture as a key driver in deforestation and degradation based on analysis of Forest Carbon Partnership Facility REDD+ Readiness Plan submissions

\begin{tabular}{|c|c|c|}
\hline Country & $\begin{array}{c}\text { Agriculture is primary } \\
\text { D\&D driver }\end{array}$ & $\begin{array}{l}\text { Agricultural D\&D drivers } \\
\text { commercial/industrial or } \\
\text { smallholder }\end{array}$ \\
\hline Argentina & $\checkmark$ & Industrial \\
\hline Costa Rica & $\checkmark$ & Both \\
\hline Cambodia & $\checkmark$ & Smallholder \\
\hline DR of Congo & $\checkmark$ & Smallholder \\
\hline Ethiopia & $\checkmark$ & Unknown \\
\hline Ghana & $\checkmark$ & Smallholder \\
\hline Guyana & mining & \\
\hline Indonesia ${ }^{1}$ & unknown & $\begin{array}{l}\text { Unclear. Non-government sources } \\
\text { indicate industrial agric. }\end{array}$ \\
\hline Kenya & $\checkmark$ & Smallholder \\
\hline Lao PDR & $\checkmark$ & Both \\
\hline Liberia & $\checkmark$ & Smallholder \\
\hline Nepal & Unsustainable logging & \\
\hline Madagascar & $\checkmark$ & Unknown \\
\hline Mexico & $\checkmark$ & Both \\
\hline Panama & $\checkmark$ & Both \\
\hline Republic of Congo & $\checkmark$ & Smallholder \\
\hline Suriname & unknown & Unknown \\
\hline Tanzania & $\checkmark$ & Both \\
\hline Uganda & $\checkmark$ & Unknown \\
\hline Vietnam & $\checkmark$ & Industrial \\
\hline
\end{tabular}

\section{Adequacy of the policy and programmatic response}

Full evaluation results of whether proposed REDD+ strategies and policy frameworks are adequate to affect the scope and scale of agricultural drivers are presented in column 2 of Table 2 , found below. While readiness proposals are not inferred to be final REDD strategies, they are detailed and thoughtful assessments. Overall, countries demonstrate acknowledgement of the importance of addressing agricultural drivers of D\&D, but REDD+ strategies and actions generally fail to address agricultural drivers. A summary of that evaluation was based on prioritizing country responses and identifying commonalities, which fell into the following categories: sorting out tenure and land rights; inefficiencies of agricultural systems; lack of operational clarity in draft readiness concepts; countries identified clear conflicts between 
REDD + and national agriculture (or related) policies; and linkage of REDD + to low carbon development plans and other higher-level policy platforms.

\section{Sorting out tenure and land rights}

This cross-cutting issue was cited by many countries as being a prerequisite to addressing smallholder agricultural impacts, and holds the potential to address poverty and forest-dependent people's disenfranchisement. Addressing this issue will lay the critical groundwork for designing benefit-sharing mechanisms that provide financial incentives to leave forests standing. Twelve countries cite this as critical: Argentina, DR Congo, Ethiopia, Ghana, Liberia, Nepal, Madagascar, Republic of Congo, Suriname, Tanzania, Uganda, and Vietnam. However, Nepal identifies absentee landlords with land being cultivated by tenants as problematic, but it is unclear whether the proposed activity of community forestry can address this issue. In Madagascar the issue of free access to resources is a problem, which tenure and rights can remedy. The parliament of the Republic of Congo considered a bill in 2010 on customary and cultural rights. Payments for Environmental Services systems in Costa Rica, viewed by many as a model for REDD+, have been restricted to owners and holders of natural forests under forest management regimes.

\section{Inefficiencies of agricultural production systems}

Many countries report this as problematic, particularly Vietnam, Madagascar, and Uganda. However, all countries that specify inefficiencies of agricultural production systems as directly affecting D\&D offer unclear causal pathways in their REDD+ readiness strategies. Furthermore, none of the R-PP budgets reviewed allocate funds for this purpose, beyond commissioning studies and gathering more information.

\section{Lack of operational clarity in draft readiness concepts}

Many countries emphasize the need for incentives for small producers and the agricultural sector, aligning sectoral goals and objectives, or redirecting agricultural development to degraded areas with low carbon and co-benefit values. Yet very few countries offered specific examples on how these strategies would be implemented, and whether key Ministries are devoting resources to those strategies. Other countries identify the need to scale up pilots or regional- and site-level models, but offer little detail on how success can be achieved in doing so. The Lao PDR cites an existing forest policy seeking to stabilize shifting cultivation, but this policy has had limited success. Thus, a challenge for the Lao PDR will be how to scale up the success of the model that combines agroforestry, farming and non-timber forest products introduced on the sloped northern lands. More detail is needed on how this can be achieved.

\section{Countries identified clear conflicts between REDD+ and national agriculture (or related) policies}

Argentina will be challenged to align its REDD+ strategy with a 2006 law promoting biofuel production, which promotes vegetable oils and animal fats for biofuels, and sugar cane, corn, sorghum for bioethanol. The R-PP does not indicate how Argentina will reconcile this policy conflict. Furthermore, Argentina stands out for taking decisive action by mandating a 
moratorium on deforestation until each province implements land use planning for national forests. However, only 4 of 25 provinces have aligned their provincial plans with the national land use plan for forests, and greater capacity and enforcement at provincial and municipal levels is cited as a major need to move this forward. Guyana's Lands \& Surveys Commission is in the process of creating regional zoning maps for appropriate uses, however mining (the largest D\&D driver) and forestry concessions are notably excluded, so any ability to link cross-sectoral strategies spatially is severely diminished. Tanzania's REDD+ objectives will have to be reconciled with Kilimo Kwanza, a national policy seeking to increase agricultural production.

\section{Linkage of REDD+ to low carbon development plans and other higher-level policy platforms}

It is noteworthy that some countries have high-level government commitments to low-carbon development paths. Ghana is one example, however more information will be required to assess how that commitment will affect national and sectoral development related to REDD+ strategy development. Kenya's Agriculture Act and recent constitution offer a strong basis for their REDD+ strategy, and a recent reversal of a previous government decision to convert a large area of the Mau forest catchment to agriculture is offered as proof that the new forest governance and policy will serve REDD+ goals. Panama exhibits strong enabling policy and governance frameworks for REDD+ via its national environmental objective (addressing both mitigation and adaptation) and constitution, which established collective ownership rights for indigenous communities and seeks to balance sustainable development and biodiversity conservation.

Finally, it is worthwhile noting that some countries have placed moratoriums on land clearing, in the hopes of stopping D\&D or arresting it until adequate planning and implementation of REDD+ (and related) strategies are carried out. As mentioned above, Argentina established a moratorium on deforestation until each province implements land use planning for national forests. The land concession moratorium announced by the Lao PDR Prime Minister in 2007 and subsequent legislation has slowed large-scale concessions, however a loophole has enabled inappropriate selection and allocation of land. And despite Cambodia's moratorium (in 2002) and cancellation of logging concessions, illegal logging for domestic use among smallholders is still a problem.

\section{Overcoming institutional and economic hurdles}

Full evaluation results of whether there are adequate cross-sectoral linkages between key government ministries (and mandates) to affect agricultural drivers are presented in column 3 of Table 2, found below. Overall, the analysis revealed that there are serious obstacles, but there also exist opportunities, to create meaningful cross-sectoral linkages that can alter strong economic forces and existing government targets and mandates. Obstacles include:

\section{Some countries simply need an adequate forestry ministry, while others clearly recognize the limits of their forest authority to address agricultural pressures}

Management of Ethiopia's forests is currently under the jurisdiction of the agriculture ministry (MoARD), however forests have been neglected in this context and the regional and business- 
oriented Regional Forest Enterprises are inadequate to serve REDD+ needs, resulting in a new emphasis on creating a dedicated federal body to manage forests. The Lao PDR acknowledges the limited jurisdiction of the forest authority, as half of national LULUCF emissions are on lands outside of their control. Tanzania notes that most D\&D occurs on 17 million hectares of 'general forest' that currently has no management regime. It should be a priority for the Tanzanian government to address this.

\section{Consultation does not infer a change in mandates}

Countries have responded to FCPF's encouragement to create cross-sectoral working groups, involve stakeholders including industry representatives from non-forestry sectors in committees, and consult with non-forestry Ministries (often via National REDD+ Steering Committees). RPP's are generally unclear how agreement and accommodation will be made on conflicting programmatic strategies and how and when tough decisions will be handled. Very few R-PP's mention the role of legislative decisions, which are often critical for changing national priorities and ministry targets and mandates.

\section{Cross-level government commitment: How REDD+ policies will affect sub-regional and district government decisions}

Kenya notes the importance of local authorities in determining land use decisions. Tanzania notes that poor governance and corruption at local, district, regional and national levels has so far restricted success of centralized forest management, participatory forest management and sustainable forest management, which are key aspects of their REDD + strategy. While Indonesia has demonstrated strong leadership on REDD + at the highest levels (most notably the President of Indonesia), the R-PP and UN-REDD Programme submission does not indicate that Ministry of Agriculture, Agriculture and National Development Planning Agency (BAPPENAS) provincial and more importantly district governments are ready to take action, amend existing mandates, and make significant changes to existing decision-making on permitted uses, which are key aspects of their jurisdictional power.

The opportunities for reconciling conflicting mandates or goals include:

\section{The importance of tools and mechanisms to reconcile conflicts}

If countries lack higher-level policies such as national low-carbon development commitments to harmonize sectoral strategies, emphasis should be placed on tools and mechanisms that inform trade-offs and reconcile conflicts. Argentina's deforestation risk index could be a powerful tool to inform future evaluation of siting of new agricultural or biofuel enterprises. Kenya shows great promise in their spatially explicit future trajectories of emissions/removals under different economic and development scenarios, which will hopefully feed into multi-sector policy and strategy development. Aligning sector plans by recalibrating targets, accounting for adaptation strategies, and creating spatially explicit and transparent multi-sector land use plans will be critical to link to newly created MRV systems. 


\section{Linking mitigation to adaptation}

Argentina, Ghana, Liberia, Nepal and Panama already have or will create Adaptation Working Groups under National Climate Change Committees and hope to link their REDD+ strategies to those. Countries that can identify REDD + priority strategies and institutions, with direct and iterative links to agriculture adaptation — such as precipitation altering agricultural production and differentiated responses of specific crops (for instance wheat being more susceptible to climate change impacts in Africa than other crops, such as millet (Müllera 2011))-will increase the ability to calibrate their policies over time.

\section{Countries that stand out as models, demonstrating strong recent interventions affecting agricultural land use patterns}

Argentina placed a 35\% export tax on soybean exportation, and its National Forest law (2007) deforestation programme is funded via a $2 \%$ tax imposed on export agriculture commodities. The budget for Argentina's deforestation programme was $\$ 100$ million in 2010. The result is that Argentina has curbed deforestation by $60 \%$ in one hotspot. Panama's community environmental business and investment programmes (as an alternative to slash-and-burn agricultural practices), and Costa Rica and Mexico's experiences with payments for environmental services stand out as success stories. 
Table 2: Evaluation of FCPF R-PP Country submissions: Influencing agricultural drivers of deforestation and degradation

\begin{tabular}{|c|c|c|}
\hline Country & $\begin{array}{l}\text { Is proposed REDD+ strategy adequate to affect } \\
\text { agricultural drivers of D\&D? }\end{array}$ & $\begin{array}{l}\text { Clear enough multi-sectoral links to affect } \\
\text { agricultural drivers of D\&D? }\end{array}$ \\
\hline Argentina & $\begin{array}{l}\text {-Strong track-record of government intervention: } 35 \% \text { export tax on soybean } \\
\text { exportation, National Forest law of } 2007 \text { already curbed deforest. by } 60 \% \text { in } \\
\text { one hotspot (programme funded via } 2 \% \text { of tax imposed on export agriculture } \\
\text { commodities (budget is } \$ 100 \text { million in } 2010) \text { ). } \\
\text {-Focus of building on National Forest Law, to improve data, MRV system, land } \\
\text { tenure systems and benefit-sharing, and expanding income-generating } \\
\text { activities for forest-dwelling communities makes sense. } \\
\text {-Not clear how incentives for small producers and the agricultural sector will } \\
\text { be operationalized. }\end{array}$ & $\begin{array}{l}\text {-Finding a way to align REDD strategy with the } 2006 \text { law } \\
\text { promoting biofuel production will be key. } \\
\text { - Moratorium on deforestation until each province } \\
\text { implements land use planning for national forests (OTBN). } \\
\text { Only } 4 \text { of } 25 \text { provinces have aligned provincial } \\
\text { plans/regulations with OTBN, thus need much greater } \\
\text { capacity and enforcement at provincial and municipal } \\
\text { levels. Should consider linking OTBN to larger-scale land } \\
\text { use plans (including agriculture). } \\
\text { - Deforestation risk index will help drive action. }\end{array}$ \\
\hline Costa Rica & $\begin{array}{l}\text {-Government lending policies seem largest hurdle, but strategy does not } \\
\text { address how to rectify this. } \\
\text {-Expansion of Payment for Environmental Services Program critical, especially } \\
\text { with smallholders. }\end{array}$ & $\begin{array}{l}\text { Need to align REDD+ strategy with new government } \\
\text { "Creation of a National Agricultural and Rural Development } \\
\text { Strategy for the 2010-2020 period", which supports } \\
\text { producers in expanding production to export markets. }\end{array}$ \\
\hline Cambodia & $\begin{array}{l}\text { The following are good candidate strategies: } \\
\text { - Promote agricultural intensification in existing large farming landscapes; } \\
\text { - Redirect agricultural development to degraded areas with low carbon and } \\
\text { co-benefit values } \\
\text { - Review regulations for land concessions and increase land use planning }\end{array}$ & $\begin{array}{l}\text { Unknown at this time, as it is unclear how candidate } \\
\text { strategies would be endorsed and supported by other } \\
\text { Ministries, unclear how to align recent economic land } \\
\text { concessions with REDD+, (concessions amount to } 6 \% \text { of } \\
\text { land area, and do not include provincial concessions) and } \\
\text { illegal logging still rampant despite } 2002 \text { moratorium. }\end{array}$ \\
\hline DR of Congo & Unclear at this time- main emphasis on data collection & $\begin{array}{l}\text { REDD policies not yet aligned with poverty reduction and } \\
\text { sectoral programme strategies. No clear plan or timeline } \\
\text { on how to achieve this. }\end{array}$ \\
\hline Ethiopia & $\begin{array}{l}\text {-Clearly the policy focus on smallholders, providing methods for } \\
\text { reforestation, PFM, agroforestry and agricultural intensification are very } \\
\text { important. However, need a parallel strategy to counter strong federal-level } \\
\text { policies promoting conversion. } \\
\text {-Also need an adequate forestry ministry to be built (regional and business- }\end{array}$ & $\begin{array}{l}\text {-While MoARD has one seat on Enviro Council and REDD } \\
\text { Steering Committee, not clear this is enough to } \\
\text { counterbalance strong GoE policy objectives supporting } \\
\text { industrial agriculture and biofuel expansion. }\end{array}$ \\
\hline
\end{tabular}




\begin{tabular}{|c|c|c|}
\hline & $\begin{array}{l}\text { oriented Regional Forest Enterprises are not enough)! Should be a larger } \\
\text { part of R-PP and REDD+ readiness. }\end{array}$ & -Need a stronger governance and enabling environment. \\
\hline Ghana & $\begin{array}{l}\text {-Unknown at this time, presume this will be clearer after policy studies are } \\
\text { completed. } \\
\text {-Critical to mainstream REDD+ with new low carbon growth plan (national } \\
\text { and sectoral developments) } \\
\text {-Reform tree tenure regime and benefit-sharing to agric. small-holders. } \\
\text {-REDD+ (shade) friendly cocoa work group critical- how to promote shade- } \\
\text { varieties at scale }\end{array}$ & $\begin{array}{l}\text {-The Cabinet level political body (ENRAC) and National } \\
\text { Climate Change Committee are well positioned to promote } \\
\text { multi-sectoral mitigation and adaptation policies. } \\
\text {-Need more information on how the comprehensive low } \\
\text { carbon growth plan will achieve this (spatial plans, legal } \\
\text { tools, etc.) and overcome current lack of institutional } \\
\text { means to address multi-sectoral conflicts. }\end{array}$ \\
\hline Guyana & $\begin{array}{l}\text {-Unclear whether training and capacity-building in the mining sector will alter } \\
\text { mining activity. Also noted projects currently in permitting pipeline will } \\
\text { continue. } \\
\text {-Need more info on how agroforestry and community agroforestry as } \\
\text { solutions in REDD+ can be operationalized, as well as system of benefit- } \\
\text { sharing. }\end{array}$ & $\begin{array}{l}\text {-Low Carbon Development Strategy may be best route to } \\
\text { reconcile sectoral differences. } \\
\text {-GL\&SC in process of creating regional zoning maps for } \\
\text { appropriate uses, but EXCLUDES mining and forestry } \\
\text { concessions. } \\
\text { - Mining activities on State Land managed by GGMC and } \\
\text { forestry activities in State Forests by the GFC, and while } \\
\text { needed coordination is referenced, R-PP contains no clear } \\
\text { policy route to reconcile these. }\end{array}$ \\
\hline Indonesia & $\begin{array}{l}\text {-Policies are not yet developed, will be explored. } \\
\text {-District-level spatial planning key, but R-Plan should identify how those } \\
\text { outputs will be codified (does not mention that Multi-stakeholder-endorsed } \\
\text { District plans for REDD must have endorsement from MOA or Agricultural } \\
\text { and National Development Planning Agency (BAPPENAS)). }\end{array}$ & $\begin{array}{l}\text { Does not indicate MOA, BAPPENAS or provincial and more } \\
\text { importantly District governments are ready to take action, } \\
\text { amend existing mandates, and make significant changes to } \\
\text { existing decision-making on permitted uses. It is noted } \\
\text { BAPPENAS sits on Nat'I REDD Programme Exec. Board. }\end{array}$ \\
\hline Kenya & $\begin{array}{l}\text {-Unclear whether REDD policy will affect Local Authority decisions. } \\
\text {-Strong higher-level directives (Agriculture Act and recent Constitution) are } \\
\text { promising, though R-PP not clear on exactly how this will affect D\&D drivers. } \\
\text { More work needed on driver assessment. } \\
\text {-Recent reversal of previous government decision to convert a large area of } \\
\text { the Mau forest catchment to agriculture viewed as proof of new forest } \\
\text { governance/policy serving REDD+ needs. }\end{array}$ & $\begin{array}{l}\text {-Integration of REDD+ into broader climate change and } \\
\text { sustainable development planning and National Climate } \\
\text { Change Response Strategy is key. Need to feed spatially- } \\
\text { explicit future trajectories of emissions/removals under } \\
\text { different economic and development scenarios into multi- } \\
\text { sectoral policy and strategy development. } \\
\text {-Proposed new constitution= tree cover of at least } 10 \% \text { of } \\
\text { the land area of Kenya (Article } 69 \text { (1)(b)) will help align } \\
\text { multi-sectoral and regional interests. }\end{array}$ \\
\hline
\end{tabular}


Lao PDR

-It is noted a major aim of forest policy has been the stabilization of shifting cultivation, but with limited success.

- Addressing shifting cultivation via extension to ethnic group communities on agroforestry- need to see how the model introduced on the sloped northern lands designed by farmers, based on their experiences with NTFPs can be reinforced and expanded.

Liberia

Nepal

-Proposed actions seem adequate, however R-PP admits Conservation Agriculture could be a 10 -year process, still needs to be streamlined into MoA, MoA currently under capacity to take on. Other options: irrigated lowland rice cultivation or subsidizing fertilizer inputs.

-Good precedence: New Forestry Reform Law (2006); est. Community

Forestry Development Committee's, resulting in annulled forest concession contracts, national and community level forest management processes and benefit sharing. Also VPA. Must do more to sort out customary land rights.

- Still unknown as REDD strategy not yet finalized

- Land reform and consolidation of smallholdings critical: Especially in Terai, land owned by absentee landlords and cultivated by tenants.

-Community forestry already demonstrated as successful in reducing poverty, increasing forest cover, and creating rural employment (except in Terai).

\footnotetext{
Madagascar

The current system of free access to resources and inefficiency of traditional agricultural systems is huge-local tenure systems, integrated planning at all scales, effective forest governance, and benefit-sharing systems addressing rural poverty and food security will be essential for REDD+ to succeed beyond pilots.
}

Mexico
-Deforestation risk index, track record of ROCYMAF, and PES program hold potential. Unclear whether ProArbol (to promote reforestation and SFM), PROCAMPO (promotes cultivation of corn and beans) and PROGAN (promoting animal husbandry) are effective as models for REDD.

- Consideration of economic incentives quite robust; i.e. valuation index on ecosystem services at the community level, spatially-explicit study on opportunity costs of non-forest land use options.
-Half the emissions from LULUCF are on lands forest authorities control, the rest is dependent on decisions and actions by other sectors that require land for other purposes.

-Not clear how gov't will influence the massive influx of Foreign Direct Investment for cash crops and plantations, especially when this is supported by the agriculture policy priorities.

-The Food and Agricultural Policy and Strategy (FAPS) lists forestry, natural resources management and climate change as key action areas which serves to commit MOA to REDD

-Good consideration of enabling laws necessary for REDD, particularly legislative enactment.

-Must resolve contention between the sector ministries.

Very solid acknowledgement of the necessity of combining food security, adaptation and mitigation together, as well as rural poverty, tenure and governance. Will take much more fleshing out to identify specific actions where gov't can influence outcome.

Unclear at this time. First objective is to address tenure and forest governance institutions.

-Once REDD Work Group is in place, role of SAGARPA may increase. Much will depend on role of the Climate Change Intergovernmental Commission in driving policy agenda, ability for risk index and land use tools to drill down to detail needed to drive land use decisions, as well as macroeconomic aspects of trade relations with the US. 


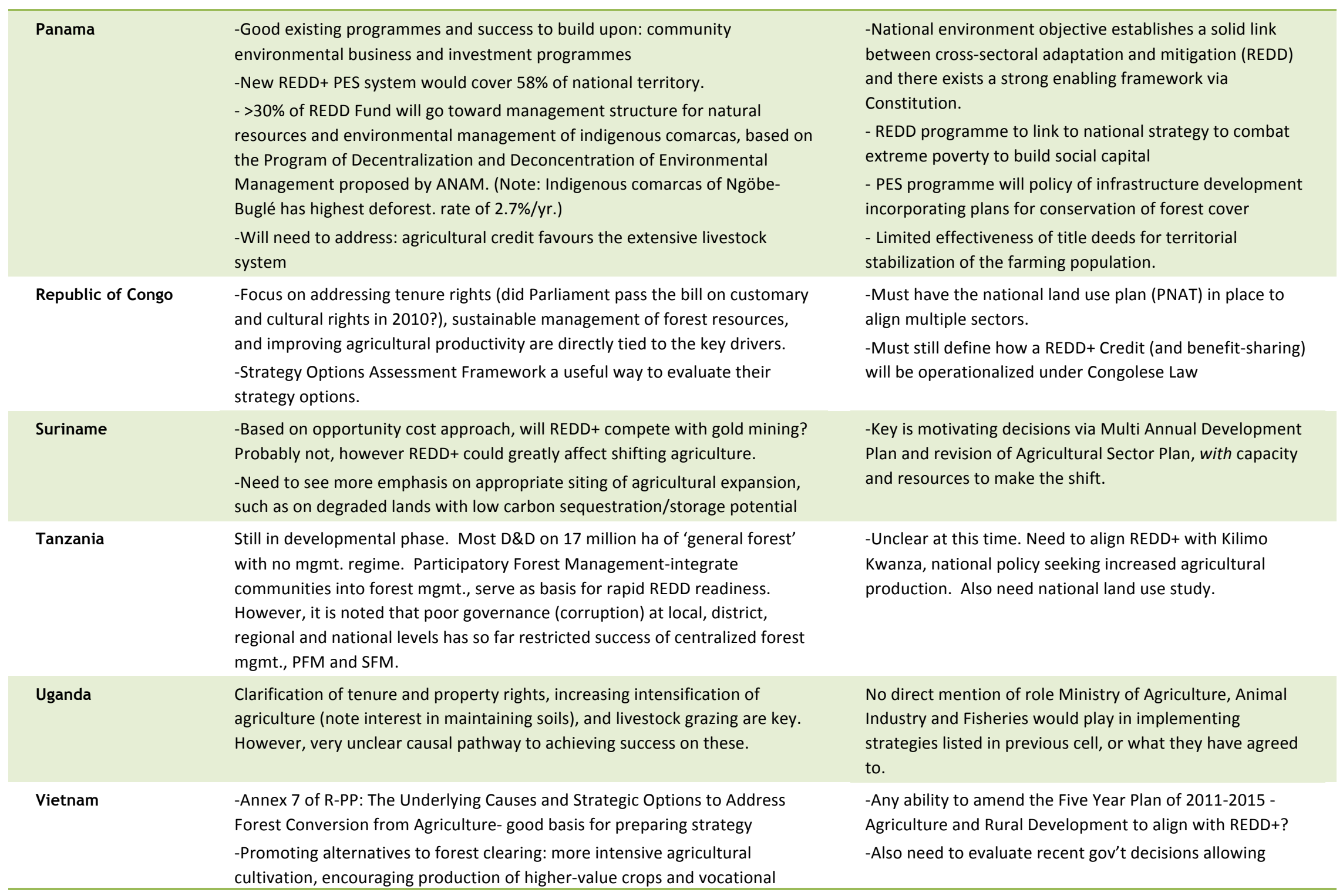


training for off-farm income opportunities.

-Independent international auditor review and assessment provincial and district Socio-economic Development Plans relevant to REDD+: good, ensure results feed back into strategy development
100,000 ha of rubber plantations in central highlands.

-Future agricultural policies will stabilize area for coffee, but rubber and cashew will increase. How to align with REDD+?

-Massive reallocation of tenure to local communities and legal entities (away from state agencies and local authorities), though hampered by lack of funding and overlapping mandate with MONRE, which oversees land allocation and MARD, in charge of forestland. 


\section{Case study: Success in Brazil and the State of Acre}

\section{Brazil}

Brazil offers a unique example of increased agricultural production, while simultaneously decreasing national rates of deforestation, and has achieved results even prior to finalization of national and state REDD+ strategies. While not participating in the FCPF process, Brazil has signed a bilateral partnership agreement with the Government of Norway and participates in the Forest Investment Programme as a pilot country.

Brazil's agricultural gains over the past decade are astonishing: Brazil's grain production increased 99\% between 1996 and 2010 (Government of Brazil IPEADATA). Brazil ranks number one in world production and exports of coffee, sugar, and frozen concentrate orange juice; number two in soybeans, tobacco, beef, and poultry (USDA 2011). Between 1990 and 2008, soybean production increased 196\% (Zanon and Saes 2010). The revolutionary increase in national agricultural production is largely attributed to the Brazilian Agricultural Research Corporations' (Embrapa) “system approach"-improving soil in the cerrado grasslands (by adding lime and techniques for fixing nitrogen that decreased use of fertilizers); adapting the African brachiaria grass to Brazil's cerrado, opening up formerly unsuitable areas to livestock production; and finally, with cross-breeding, adapted soybeans (typically a temperate crop) to a tropical climate with acidic soil.

Brazil's National Institute for Space Research (INPE) announced deforestation in the Amazon over 2009-2010 decreased 13.6\% from the previous year, and is the lowest rate measured by INPE since 1988, when INPE's annual surveys began (National Institute for Space Research 2010). Brazil has launched the second phase of the National Plan for the Prevention and Control of Deforestation in the Legal Amazonia. However, recent scrutiny over Cargill's soya production practices in Santarém, Pará state, raises questions about accuracy of satellitemonitoring systems that until two years ago were incapable of detecting deforestation on individual farms (Nature 2011). Furthermore, there are dramatic regional differences in deforestation rates, and not all forest biomes are consistently included in deforestation estimates, such that clearing of the cerrado in Mato Grosso was omitted from deforestation estimates provided to the California Governor's Climate and Forests Task Force (Filho 2010), 
while it is considered an important forest class in that state. Brazil is preparing the National Plan for Prevention and Control of Deforestation for the second most relevant biome in Brazil, the cerrado (Brazil Ministry of Finance No date).

In 2009, Brazil established an economy-wide target to reduce carbon emissions between 36.1 and $38.9 \%$ by 2020 compared to a reference scenario of business as usual. The target was incorporated in the National Policy on Climate Change, ratified by Congress. Plans to reduce emissions in different economic sectors are being developed in consultation with the civil society in the sectors of energy, agriculture and in the steel industry. In total, twelve sectoral plans will be implemented by the end of 2011 (Teixeira 2010). In July 2010, Brazil's ban on the commercialization of soy grown in the Amazon was extended for the fourth consecutive year (reinforced by the Bank of Brazil's December 2010 announcement that it will veto agricultural credit for soy farmers who want to plant in newly cleared forest), a critical output of cross-sectoral pacts.

One of Brazil's largest export products is ethanol. The Brazilian National Agroenergy Plan seems to reinforce the objectives of its 2004 Action Plan for Deforestation Control and Prevention in the Amazon, as the Agroenergy Plan guides future siting to "Optimizing the use of areas affected by human action on natural vegetation (anthropic impact), maximizing the sustainability of the production systems, discouraging unjustifiable expansions of the agricultural frontier and encroachment upon sensitive or protected systems, such as the Amazon Forest and the Pantanal region, inter alia, should be discouraged. Bioenergy projects could also contribute to the reclamation of degraded areas." (Brazil Ministry of Agriculture, Livestock and Food Supply 2006, p. 11) It will be important to monitor whether future biofuel expansion and siting upholds the intent of this section.

\section{Acre State}

Seven of the nine Amazon states have already developed and approved their own action plans to fight deforestation at the local level. Acre State is an impressive example of how a subregional REDD+ programme seeks to fulfil emissions reductions from D\&D while bringing small-, medium- and large-scale producers into its programmatic objectives. 
The programme encompasses all lands and use types, including the full-range of agricultural uses that impact Acre's forests

The programme is not limited to state lands or forest resources, but rather encompasses private and public lands, protected areas agricultural land, and indigenous lands.

Implementation across the landscape is to occur through a phased approach.

The programme offers a mix of incentives and payments, bundled under an umbrella REDD+ programme tied directly into the Acre Sustainable Development Plan, including:

1) a Programme for Valuing Environmental Assets_-including best practices and property certification (including payments) for family farming in already cleared or altered areas, and support for forest management in intact forests, and 2) the Recuperation of Altered Areas Programme - including reforestation, agroforestry and ranching on cleared and degraded areas, and 3) the Carbon ISA Program — established to create and implement economic and financial instruments to achieve emission reduction targets, infrastructure and instruments for measurement, quantification and verification, with registration and transparency (MQVRT), strengthening the cooperation and alignment at the international, national, subnational and local levels, benefit-sharing, and promoting a new model of sustainable local and regional low carbon development. (State of Acre 2010, p. 14).

\section{The programme is nested within federal targets}

Acre's emissions reduction target mandates compliance and alignment "with the goal of reducing emissions, contained in Federal Law number 12.187 of 2009" (State of Acre 2010, p. 2). It mirrors the $80 \%$ Amazon deforestation reduction target.

\section{The programme is based on multi-sectoral land use plans}

"Compliance, by programs linked to SISA, with the provisions set forth in the Law number 1.904 of June 5, 2007, which established ZEE/AC (Ecological-Economic Zoning of the State of Acre) (State of Acre 2010, p. 2)." Acre's zoning initiative reflects the strategy and approach of the Amazon Ecological-Economic Macrozoning initiative (MacroZEE), announced in March 2010, which guides, at a regional scale, the design and spatial distribution of public policies for development, territorial planning and the environment, based upon sustainability criteria. Deforestation will be avoided by halting the expansion of 
agriculture and cattle ranching into areas of native vegetation, and promoting the use and recovery of degraded lands for agribusiness. (Government of Brazil 2010).

\section{Governance of the programme is strong, with enforcement ability}

A State Commission for Validation and Monitoring, the Regulation, Control and Registration Institute, Scientific Committee, Group of Councils, and the Agency for Development of Environmental Services of Acre State, a private and public joint stock corporation, overseen by the Forestry Department, charged with: developing strategies aimed at raising funds and attracting investments in programs, prepares action plans and projects, helps align financing for environmental services, and manages and disperses assets and credits arising from ecosystem services and products deriving from the programs, subprograms, plans and projects. (State of Acre 2010, p. 11) 


\section{Roadmap for how to address agricultural drivers in REDD+ strategies}

What follows is a skeletal roadmap for how countries can more adequately address agricultural drivers of D\&D in their REDD+ strategies. Individual countries should consider these, but must ultimately tailor strategies to suit the specific agricultural drivers and national/regional contexts.

\section{Identify clear strategies to address demand-side and market pressures, and how government action can influence those}

For countries facing commercial/industrial-scale agriculture pressures, this is of great urgency. Countries should start by addressing the appropriate siting of small- and large-scale agricultural expansion vis-à-vis their REDD+ strategies. However, countries will need to more directly engage mechanisms that can influence marketplace demand, such as certification and influencing lending policies.

- Countries can encourage agricultural product certification systems that will steer investment and demand to agricultural producers and products that meet certification standards - such as endorsement and promotion of the Roundtable for Sustainable Palm Oil, principles and certification standards of the Roundtable on Sustainable Biofuels, and the Sustainable Agriculture Network (operating in Central and South America). As mentioned above, Acre State, Brazil also offers a model for how to promote best practices and property certification (including payments) for small and large agricultural producers via their Programme for Valuing Environmental Assets, an integral part of their statewide REDD+ strategy.

- There is a growing trend towards application of procurement policies and supply chain transparency, particularly for controversial products. In recent years, scrutiny of illegally harvested timber has increased, with France, Germany and the United Kingdom adopting green public procurement policies affecting illegally harvested 
wood, and increasingly considering similar commitments related to agricultural products. The World Bank Group recently adopted a framework and International Finance Corporation strategy to guide future engagement in the global palm oil sector. Countries will increasingly need to consider those external commitments, but can also shape domestic lending guidelines applied to loans and investment decisions by banks, such as the Bank of Brazil December 2010 announcement that it will veto agricultural credit for soy farmers who want to plant in newly cleared areas of the Amazon forest.

\section{Strengthen cross-sectoral policy and implementation alignment}

Countries with clear conflicts between REDD+ and national/regional agriculture (or related) policies must put this first on the agenda for multi-Ministerial decisions and identify clearly the pathways to bring resolution (legislative decisions, further stakeholder input, etc.).

- Further, place emphasis on development of tools and mechanisms, linked to policy formulation, that help reconcile sectoral conflicts, such as Argentina's deforestation risk index and Kenya's spatially-explicit future trajectories of emissions/removals under different economic and development scenarios. Effective land use planning is also a critical basis for aligning sectoral interests, and demarcating how to overcome differences in jurisdictional power between national, regional and district levels of government.

- Link REDD+ to low carbon development plans and other higher-level policy platforms in order to create strong enabling legal institutional frameworks.

\section{Sort out tenure and land access rights}

Reconciling tenure and access rights is crosscutting and fundamental in many R-PP's that cite smallholder agriculture impacts. Those governments should focus energies immediately on increasing forest-dependent and indigenous people's access to forests and bringing certainty to their ability to gain tenure and access benefit-sharing.

\section{Link mitigation to adaptation}

Countries must link forest and agriculture strategies addressing both mitigation and adaption approaches to identify how to meet domestic food supply needs in the future (given 
population growth, increasing urbanization, regional changes in precipitation and other climate change impacts), while safeguarding carbon stocks.

\section{Boost efficiency and production of agricultural systems}

REDD+ strategies can promote more efficient use of land by steering agricultural expansion to already degraded lands (that hold low potential for recruiting carbon-rich regeneration of forests) and can help to steer agricultural extension services to priority landscapes and/or those with greatest potential conflicts with the REDD+ strategy. In countries where shifting agriculture (smallholder impacts) is problematic, a mixture of settling access and tenure rights plus extension programmes (such as Liberia's conservation agriculture), depending on the circumstances, will be critical. Emphasis should also be placed on promoting agricultural intensification activities that also increase carbon storage (such as agroforestry), combine animal husbandry and food production (Mexico's PROGAN ecológico) and are geared towards increasing soil fertility (Brazil's success with techniques for fixing nitrogen that decreased use of fertilizers is a model). Countries should apply REDD + readiness funding to furthering this goal.

\section{National MRV systems incorporate agricultural carbon measurement}

Increasingly, countries are recognizing the benefits of greenhouse gas inventories that include all land-uses to track changes in all terrestrial carbon pools. While the financing and capacity may not exist now in many countries to achieve this, building data inventories and tracking agricultural uses/carbon emissions in the design of MRV systems for REDD+ will help address an informational shortcoming many countries identified related to the role of agriculture in forest clearing. Such information is critical in fine-tuning national and regional REDD+ and agriculture policy development. 


\section{Conclusion}

REDD + offers an unprecedented opportunity to establish policies, institutions and capacity to address agricultural drivers of land conversion. The review of FCPF R-PP's illustrates that many countries have a long way to go before fundamentally addressing agricultural drivers of D\&D.

While there is a need to focus REDD+ investment in bolstering national-level forest governance, particularly in countries facing illegal logging and inadequate forest-sector institutions, focusing only on the forest sector is not enough to confront and reconcile agricultural drivers of forest clearing. This paper argues that in order for REDD + carbon emission mitigation goals to be reached,

1) the primary driver of forest clearing globally—agriculture — must be fundamentally addressed by aligning REDD + targets with transformational change in agricultural systems that intensify production, satisfy domestic needs before serving export markets, are geared towards stabilizing food-security in the face of increasing climate change impacts, and solidify forest-dependent community and smallholder tenure and access rights, and

2) national governments engaging in REDD+ must focus their REDD+ readiness activities and development of national strategies on establishing and enabling adequate legal institutional frameworks (such as low-carbon development commitments); governance; and measurement, monitoring and reporting (MRV) systems that account for and are responsive to the role of agriculture in forest clearing, stretch beyond the forest sector, and align long-term objectives of safeguarding terrestrial carbon stocks while providing food for a growing population. 


\section{References}

Argentina REDD+ Readiness Preparation Proposal (R-PP). 2010. Submitted to Forest Carbon Partnership Facility, June 2010.

Costa Rica REDD+ Readiness Preparation Proposal. 2010. Submitted to Forest Carbon Partnership Facility, August 2010.

Cambodia Final REDD+ Readiness Preparation Proposal R-PP. 2011. Submitted to Forest Carbon Partnership Facility, January 2011.

Brazil Ministry of Agriculture, Livestock and Food Supply. 2006. Brazilian Agroenergy Pan 2006-2011. Brasília, DF: Embrapa Publishing House.

Brazil Ministry of Finance. No date. Confirmation of Government Agreement to Participate in the Forest Investment Program. Submitted to Climate Investment Funds. (Available from http://www.climateinvestmentfunds.org/cif/sites/climateinvestmentfunds.org/files/Brazil_ Confirmation of Interest.pdf)

DeFries R, Rudel TK, Uriarte M, Hansen M. 2010. Deforestation driven by urban population growth and agricultural trade in the twenty-first century. Nature Geoscience 3: 178-181.

Democratic Republic of Congo REDD+ Readiness Preparation Proposal R-PP. 2010. Submitted to Forest Carbon Partnership Facility, July 2010.

Ethiopia REDD+ Readiness Preparation Proposal R-PP. 2011. Submitted to Forest Carbon Partnership Facility, January 2011.

European Parliament. 2010. Fact Sheet: The Doha Round and Agriculture. (Available from http://www.europarl.europa.eu/parliament/expert/displayFtu.do?language=en\&id=73\&ftuI $\mathrm{d}=$ FTU_4.2.8.html)

Forest Carbon Partnership Facility (FCPF). 2010. Readiness Preparation Proposal (R-PP) Template, version 4.

Ghana REDD+ Readiness Preparation Proposal R-PP. 2010. Submitted to Forest Carbon Partnership Facility, December 2010.

Gibbs HK, Ruesch AS, Achard F, Clayton MK, Holmgren P, Ramankutty N, Foley JA. 2010. Tropical forests were the primary sources of new agricultural land in the 1980s and 1990s. Proceedings of the National Academy of Sciences_107: 16732-16737.

Filho LM. 2010. Governor's Climate and Forests Task Force- Brazilian Members' Database Analysis. Task 3 Report, Version 2.0.

Food and Agriculture Organization (FAO). 2009. How to Feed the Word in 2050. Discussion paper prepared for Expert Forum: 12-13 October 2009, Rome. 
Government of Brazil. IPEADATA macroeconomic database. (Available from http://www.ipeadata.gov.br/Default.aspx)

Government of Brazil. 2010. Amazon Ecological-Economic Macro-Zoning defines measures to fight deforestation. (Available from http://www.brasil.gov.br/news/history/2010/03/26/amazon-ecological-economic-macrozoning-defines-measures-to-fight-deforestation/newsitem_view?set_language=en)

Guyana REDD+ Readiness Preparation Proposal R-PP. 2010. Submitted to Forest Carbon Partnership Facility, April 2010.

Hoffman U. 2011. Assuring Food Security in Developing Countries under the Challenges of Climate Change: Key Trade and Development Issues of a Fundamental Transformation of Agriculture. UNCTAD/OSG/DP/2011/1.

Indonesia UN-REDD National Joint Programme Document. 2009. Government of Indonesia, UNEP, FAO, UNDP. October 2009.

Indonesia REDD+ Readiness Plan (R-Plan). 2009. Submitted to Forest Carbon Partnership Facility, May 2009.

Intergovernmental Panel on Climate Change (IPCC). 2007. Climate Change 2007: Synthesis Report. Geneva, IPCC.

Kenya REDD+ Readiness Preparation Proposal (R-PP). 2010. Submitted to Forest Carbon Partnership Facility, August 2010.

Koh LP, Miettinen J, Liew SC, Ghazoul J. 2011. Remotely sensed evidence of tropical peatland conversion to oil palm. Proceedings of the National Academy of Sciences 108: 5127-5132.

Lao People's Democratic Republic REDD+ Readiness Preparation Proposal (R-PP). 2010. Submitted to Forest Carbon Partnership Facility, October 2010.

Liberia Draft REDD+ Readiness Preparation Proposal (R-PP). 2011. Submitted to Forest Carbon Partnership Facility, January 2011.

National Institute for Space Research. 2010. Amazon deforestation has been decreased 14\% INPE estimates 6,451 km2 for 2009/2010 periods. Press release (Available from http://www.inpe.br/ingles/news/news_dest154.php) (Accessed on 1 December 2010)

Nature. 2011. Editorial: Soya scrutiny: A partnership to encourage sustainable farming in Brazil may not be as green as it seems. Nature 472: 5-6.

Nepal REDD+ Readiness Preparation Proposal (R-PP). 2010. Submitted to Forest Carbon Partnership Facility, October 2010.

Madagascar Revised REDD+ Readiness Preparation Proposal (R-PP). 2010. Submitted to Forest Carbon Partnership Facility, October 2010. 
Mexico REDD+ Readiness Preparation Proposal (R-PP). 2010. Submitted to Forest Carbon Partnership Facility, February 2010.

Müllera C, Cramera W, Harea WL, Lotze-Campena H. 2011. Climate change risks for African agriculture. Proceedings of the National Academy of Sciences 108: 4313-4315.

Panama REDD+ Readiness Preparation Proposal R-Plan. 2009. Submitted to Forest Carbon Partnership Facility, May 2009.

Republic of Congo REDD+ Readiness Preparation Proposal (R-PP). 2010. Submitted to Forest Carbon Partnership Facility, April 2010.

State of Acre, Brazil. 2010. Bill No. 2.308: To create the State System of Incentives for Environmental Services (SISA). Unofficial translation.

Suriname Draft REDD+ Readiness Preparation Proposal (R-PP). 2010. Submitted to Forest Carbon Partnership Facility, January 2010.

Tanzania Readiness Preparation Proposal (R-PP). 2010. Submitted to Forest Carbon Partnership Facility, October 2010.

Teixeira I. 2010. Statement of Ms. Izabella Teixeira, Minister of Environment of Brazil, to the General Debate of COP 16. (Available from http://www.brasil.gov.br/news/history/2010/12/09/statement-of-ms.-izabella-teixeiraminister-of-environment-of-brazil-to-the-general-debate-of-cop-16) (Accessed on 9 December 2010)

Uganda Draft Readiness Preparation Proposal (R-PP). 2011. Submitted to Forest Carbon Partnership Facility, January 2011.

US Department of Agriculture (USDA). 2011. Foreign Agricultural Service, Country Report for Brazil. (Available from http://www.fas.usda.gov/country/Brazil/Brazil.asp

van der Werf GR, Morton DC, DeFries RS, Olivier JGJ, Kasibhatla PS, Jackson RB, Collatz GJ, Randerson JT. 2009. $\mathrm{CO}_{2}$ emissions from forest loss. Nature Geoscience 2: 737 - 738 (Available from www.biology.duke.edu/jackson/ng09.pdf)

Vietnam Draft Readiness Preparation Proposal (R-PP). 2010. Submitted to Forest Carbon Partnership Facility, October 2010.

Zanon RS, Saes MSM. 2010. Soybean Production in Brazil: Main Determinants of Property Sizes. Proceedings in Food System Dynamics 2010. (Available from http://centmapress.ilb.uni-bonn.de/ojs/index.php/proceedings/article/view/57/55) 


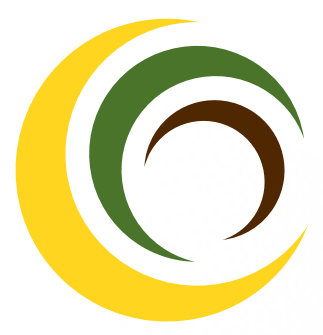

The CGIAR Research Program on Climate Change, Agriculture and Food Security (CCAFS) is a strategic initiative of the Consultative Group on International Agricultural Research (CGIAR) and the Earth System Science Partnership (ESSP), led by the International Center for Tropical Agriculture (CIAT). CCAFS is the world's most comprehensive global research program to examine and address the critical interactions between climate change, agriculture and food security.

\section{For more information, visit www.ccafs.cgiar.org}

Titles in this Working Paper series aim to disseminate interim climate change, agriculture and food security research and practices and stimulate feedback from the scientific community.
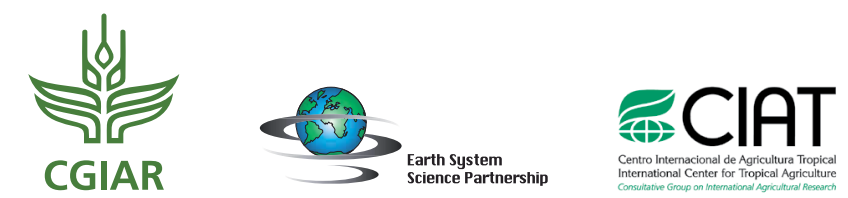

\section{LEXEME}

consulting 